\title{
The EU as a friend of the developing world? Self- portrayal and outside perceptions in the negotiations of EPAs
}

Citation for published version (APA):

Weinhardt, C. (2011). The EU as a friend of the developing world? Self-portrayal and outside perceptions in the negotiations of EPAs. In J. Lieb, N. von Ondarza, \& D. Schwarzer (Eds.), The European Union in International Fora (pp. 99-114). Nomos. https://doi.org/10.5771/9783845233024-99

Document status and date:

Published: 01/01/2011

DOI:

10.5771/9783845233024-99

Document Version:

Publisher's PDF, also known as Version of record

Document license:

Taverne

Please check the document version of this publication:

- A submitted manuscript is the version of the article upon submission and before peer-review. There can be important differences between the submitted version and the official published version of record.

People interested in the research are advised to contact the author for the final version of the publication, or visit the DOI to the publisher's website.

- The final author version and the galley proof are versions of the publication after peer review.

- The final published version features the final layout of the paper including the volume, issue and page numbers.

Link to publication

\footnotetext{
General rights rights.

- You may freely distribute the URL identifying the publication in the public portal. please follow below link for the End User Agreement:

www.umlib.nl/taverne-license

Take down policy

If you believe that this document breaches copyright please contact us at:

repository@maastrichtuniversity.nl

providing details and we will investigate your claim.
}

Copyright and moral rights for the publications made accessible in the public portal are retained by the authors and/or other copyright owners and it is a condition of accessing publications that users recognise and abide by the legal requirements associated with these

- Users may download and print one copy of any publication from the public portal for the purpose of private study or research.

- You may not further distribute the material or use it for any profit-making activity or commercial gain

If the publication is distributed under the terms of Article $25 \mathrm{fa}$ of the Dutch Copyright Act, indicated by the "Taverne" license above, 


\title{
The EU as a friend of the developing world? Self-portrayal and outside perceptions in the negotiations of Economic Partnership Agreements
}

\author{
Clara Weinhardt
}

This contribution analyses the role of the EU in the negotiations on Economic Partnership Agreements (EPAs) with African, Caribbean and Pacific countries. The EPAs build upon the network of bilateral and regional trade agreements the EU has concluded since the establishment of its common market, first starting with former Belgian, French and later British colonies, allowing them preferred market access in order to maintain the close economic relationships between those countries and the EU. Gradually, the number of preferential or free-trade agreements undertaken by the EU extended far beyond the reach of the former close economic relationships of individual EU countries. In the case of the EPAs that the European Commission is negotiating with 78 African, Caribbean and Pacific countries, the EU has continuously portrayed itself as a benign actor, using the trade agreements to support developing countries. Yet, research conducted on its partner countries shows that the EU is perceived as pursuing its own economic self interests, and has not yet found common ground with the African, Caribbean and Pacific countries concerning the EPAs. In light of this critical perception from its external partners, the question on how the EU wants to use its trade policy as part of its overall external policy toolbox thus becomes more relevant than ever.

\section{Introduction}

The Lisbon Treaty bears the promise of improving the European Union's ability to act on the international scene. Whether policy initiatives taken by the EU reach their goals, however, is not solely determined by institutional factors as such, but also by the way in which others perceive the EU. ${ }^{1}$ If the EU wants to negotiate efficient policies, it needs to take into account expectations and percep-

1 Natalia Chaban et al, "The European Union as others see it", European foreign affairs review 11, 2 (2006): 247. 
tions in the rest of the world. ${ }^{2}$ Until recently, research has rarely paid attention to how its partners regard the EU. ${ }^{3}$ This chapter aims to contribute to filling this empirical gap by highlighting outside perceptions of the EU's role in trade negotiations with the developing world. In doing so, it examines the case of negotiations of Economic Partnership Agreements (EPAs) with African, Caribbean and Pacific (ACP) countries. EPA agreements are the latest set of trade agreements between the EU and the ACP group, granting preferential access to European markets as compared to other trade regimes with other countries.

In its external trade policy, the EU seems to aim at establishing itself as a 'friend' of the developing world. EPAs were portrayed as 'development' rather than 'commercial' free trade agreements, highlighting the EU's benevolent motives. The approach of other major players in trade, in particular China, is on the contrary criticised for disregarding long-term development implications of trade policies. ${ }^{4}$ Against the background of increasing competition from China as a trade and development actor in Africa, the EU's seems to highlight its explicit development-orientation as a bargaining card. But does it pay off in negotiations? This chapter assesses to what extent the EU's approach is indeed perceived as distinctly different on the ground. It compares the EU's self-portrayal as a 'friend' of the developing world in trade negotiations with outside perceptions. On the ACP side, this chapter focuses on the perspective of one of the six ACP negotiating regions: West Africa. This region is mostly comprised of Least Developed Countries, rendering the EU's promise to negotiate 'development' rather than 'commercial' agreements particularly important. It will be argued that the apparent discrepancy between inside and outside perceptions casts doubt on the extent to which the EU can credibly convince ACP countries that it is playing a more development-oriented role that sets its trade relations with the developing world apart from those of other global powers.

The empirical sections of this chapter rely on a combination of qualitative sources: Most importantly, this paper is based on 17 semi-structured interviews conducted with West African and EU trade representatives involved in the negotiation process of the Economic Partnership Agreements. ${ }^{5}$ It moreover relies on

2 Sonia Lucarelli, Lorenzo Fiarmonti (eds.), External perceptions of the European Union as a global actor (New York: Routledge, 2009), 1.

3 Ibid.

4 Chiwoyu Sinyangwe, "EU commissioner to meet Zambia, Malawi over EPAs", The Post Newspapers Zambia, 23 March 2010; see also Ali Zafar, "The growing relationship between China and Sub-Saharan Africa: macroeconomic, trade, investment, and aid links", The World Bank Research Observer (Washington, 2007).

5 These were either face-to-face interviews conducted in Brussels or phone-to-capital interviews. Seven interviews were conducted with West African representatives, and ten with EU trade representatives. Part of the interview data with West African representa- 
two responses to a subsequently designed comprehensive questionnaire from the West African region. Finally, it draws on the supplementary analysis of official statements by West African and EU representatives.

\section{What are Economic Partnership Agreements?}

Negotiations of the Economic Partnership Agreements began in 2002 with the aim of establishing Free Trade Areas between the European Union and six regional groupings among the ACP countries by the end of December 2007. The preferential access of the preceding Lomé IV regime (1990-2000) violated the requirement of non-discrimination among members of the World Trade Organization (WTO). The WTO waiver enabling the unilateral Lomé preferences was set to expire at the end of 2007, with little support from non-ACP developing countries for renewal. Lomé preferences were not available to all developing countries and were not restricted to least developed countries. ${ }^{6}$ Reforming the EUACP trade regime thus became necessary.

The envisaged EPAs were geared towards introducing a fundamental shift in EU-ACP trade relations: firstly, by introducing reciprocal liberalisation in trade and goods and services, and secondly, by breaking up the unity of the ACP group into six regional sub-groups as a means to further regional integration. Reciprocal liberalisation was introduced primarily to retain the WTO compatibility of the EU-ACP trade regime. If the EU and ACP countries were to establish a free trade area based on the mutual liberalisation of "substantially all trade", 7 it would allow for positive discrimination between the partners (Art. 24 General Agreement on Tariffs and Trade (GATT)). Granting special market access to ACP countries would thus not require the approval of other developing countries at the WTO. The establishment of a free trade area, however, implied substantive changes on the part of the ACP countries. Under the Lomé system of unilateral trade preferences, ACP countries could apply barriers on imports from the European Communities. ${ }^{8}$ The EPA regime hypothetically required ACP countries to

tives was collected when working as a research assistant for the Global Economic Governance Programme of Oxford University in 2008. Note that almost all interviews were taped, although all interviewees were granted confidentiality given the ongoing negotiations.

6 Arvind Panagariya, "Agricultural Liberalisation and the Least Developed Countries: Six Fallacies", The World Economy 28, 9 (2005): 1418.

7 "Substantially all trade" is commonly understood to refer to a liberalisation of $80 \%$ of trade in goods. Given the development context of EPAs, the EU suggested a liberalisation of $100 \%$ on the European side, and $80 \%$ on the ACP side.

8 “EPA Negotiations - Where do We Stand?", ECDPM, 31 March 2008. 
significantly reduce tariffs on EU imports, with full liberalisation of about 80 per cent of trade volumes. On the European side changes were minor, as most ACP imports were already subject to de facto duty and quota free market access. ${ }^{9}$ Moreover, negotiations aimed to go beyond trade in goods, including trade in services as well as provisions on investment, competition, trade facilitation and government procurement.

In addition to the requirement of WTO compatibility, the EU emphasised that the expiring Lomé waiver provided a welcome opportunity to re-think the approach to fostering development through preferential trade agreements with developing countries. The disappointing results of the Lomé regime seemed to discredit the usefulness of unilateral preferences. Despite preferential access for over 30 years, the proportion of EU imports from ACP countries dropped from 7 per cent to 3 per cent of EU imports. ${ }^{10}$ Reciprocal, albeit asymmetrical, liberalisation coupled with regional integration was hoped to constitute a more promising avenue to fostering economic development in the ACP region. ${ }^{11}$ Therefore, for the first time since the 1960s, the ACP region was split in six negotiating configurations that bilaterally engaged with the EU. ${ }^{12}$ EPA negotiations were thus geared towards introducing substantial reforms of the EU-ACP trade regime.

\section{Analytical framework: on examining perceptions}

In order to assess whether outside perceptions of the EU's role in EPA negotiations match its self-portrayal, it is necessary to uncover decision-makers' perceptions. Any inquiry engaging in the study of perceptions, however, must confront the fact that reasoning is not amenable to a positivist methodology. Doing so necessarily relies on interpretative research methods. ${ }^{13}$

9 San Bilal, "EPAs Process: Key issues and development perspective - With specific references to East and Southern Africa", paper prepared for CUTS International (2006), 15.

10 European Commission (DG Trade), "Economic Partnerships", see: <http://ec.europa.eu/trade/wider-agenda/development/economic-partnerships/> (accessed: 18 August 2010).

11 "EU Trade Policy Towards Developing Countries", conference speech of European Commissioner for Trade Karel De Gucht, (Brussels: 16 March 2010).

12 The negotiating regions were: West Africa (ECOWAS), Eastern and Southern Africa (ESA), Central Africa (CEMAC), Southern Africa (SDAC), the Pacific (PIF) and the Caribbean (CARIFORUM) region. Later on, the Eastern African Community, formerly part of ESA, was included as a seventh negotiating region.

13 Mark Neufeld, "Interpretation and the 'science' of international relations", Review of In ternational Studies 19 (1993): 39-61; Karin Fierke, “Constructivism”, International Relations Theories: Discipline and Diversity eds. Tim Dunne, Milja Kurki, Steve Smith (Oxford: Oxford University Press, 2007), 176. 
This chapter draws upon the perceptions and reasoning of actors, their 'insider view', as a source of primary data. ${ }^{14}$ According to Zartman,

"part of any social interaction is a matter of perception [...]. Perception mediates objective reality, although of course reality imposes certain limits on the implications of perceptions". 15

Perceptions are thus conceptualised as an 'intervening' variable that affect how actors make sense of 'objective' reality. The view of outside actors is therefore not necessarily a reliable indicator for how the EU is, but how the EU appears to be from a given perspective.

The empirical sections rely on the analysis of narratives as a way of accessing perceptions. ${ }^{16}$ In analogy to discourse analysis, doing so opens up the methodological challenge of distinguishing the strategic use of narratives from narratives as a reflection of genuine perceptions and beliefs. ${ }^{17}$ But, as stated by Hurd, "methodological difficulties signal potentially interesting questions, which should attract scholarly attention, not discourage it." ${ }^{, 18}$ To address these difficulties, qualitative interviews were used as a primary source of data to complement public discourses. As Mason highlights, qualitative interviews are an adequate method to explore people's reasoning processes. ${ }^{19}$ Narratives voiced in private, rather than public settings are more likely to reveal genuine perceptions. Private interviews encourage expressive, as opposed to merely the informative and directive use of language that prevails in public discourses. ${ }^{20}$

In the case of EPA negotiations, the narratives describing the EU's role will be categorised according to two possible ideal-typical descriptions: the role as a self-interested business partner and the role as a "friend", i.e. developmentoriented negotiating partner. These narratives were chosen because they broadly reflect the scope of possible roles the EU was expected to take in the course of EPA negotiations. Within policy and academic circles, both roles were frequent-

14 Jennifer Mason, Qualitative Researching (London: Sage, 2002), 56; David E. McNabb, Research Methods for Political Science: Quantitative and Qualitative Methods (London: ME Sharpe, 2004), 342.

15 I. William Zartman, Jeffrey Z. Rubin, Power and negotiation (Michigan: University of Michigan Press, 2002), 13.

16 Harry T. Reis, Charles M. Judd, Handbook of research methods in social and personality psychology (Cambridge: Cambridge University Press, 2000), 313.

17 Colin Hay, Ben Rosamond, "Globalization, European integration and the discursive construction of economic imperatives", Journal of European Public Policy 9, 2 (2001): 150.

18 Ian Hurd, "Legitimacy and authority in international politics", International Organization 53, 2 (1999): 392.

19 Jennifer Mason, Qualitative Researching (London: Sage, 2002), 56.

20 Antje Wiener, The invisible constitution of politics: contested norms and international encounters (Cambridge: Cambridge University Press, 2008), 75. 
ly alluded to. When developing possible scenarios, Marti ${ }^{21}$ for instance argues that EPAs were likely to be situated somewhere between the two frameworks of a classical regional or free trade agreement, and a comprehensive and genuine North-South partnership. The trade policy analyst Bilal likewise depicts EPAs as oscillating between a "good North-South partnership and the shrewd coldhearted free trade agreement." ${ }^{, 22}$ From an academic perspective, Elgström classifies images of the EU either as a 'demon', driven by self-interest with a hidden agenda, or an 'angel', an actor with altruistic objectives, concerned primarily with the development of ACP countries. ${ }^{23}$ Storey similarly assesses the EU as acting either as a normative power or out of a defence of mainly economic selfinterests. ${ }^{24}$ To identity both roles, narratives are assessed according to two aspects that highlight the differences between both: actor orientation and negotiation principles.

\section{Table 1 - Diverging narratives on the EU's role in EPA negotiations}

\begin{tabular}{l|l|l} 
Narrative & $\begin{array}{l}\text { EU as a } \\
\text { 'business partner' }\end{array}$ & $\begin{array}{l}\text { EU as a } \\
\text { 'distinct development partner' }\end{array}$ \\
\hline $\begin{array}{l}\text { Actor } \\
\text { orientation }\end{array}$ & $\begin{array}{l}\text { pursuit of own commercial } \\
\text { interests }\end{array}$ & pursuit of development objectives \\
\hline $\begin{array}{l}\text { Negotiation } \\
\text { principles }\end{array}$ & $\begin{array}{l}\text { tit-for-tat trade bargains: } \\
\text { sticks and carrots, } \\
\text { reciprocity }\end{array}$ & $\begin{array}{l}\text { solidarist ideas: non-coercive } \\
\text { dialogue, flexibility, care }\end{array}$ \\
\hline
\end{tabular}

Source: own compilation.

The following section highlights the EU's self-image of its role in the EPA negotiations. These self-portrayals are subsequently contrasted with the perceptions from the West Africa negotiating group.

21 Darlan F. Marti, “Updating the Economic Partnership Agreements to match today's global challenges", Trade Negotiation Insight 9, 1 (January 2010).

22 Sanoussi Bilal, "Redefining ACP-EU Trade Relations: Economic Partnership Agreements", in The Cotonou Partnership Agreement: What Role in a Changing World? ed. Geert Laporte (European Centre for Development Policy Management, 2007).

23 Ole Elgström, "Images of the EU in EPA negotiations: Angel, demon - or just human?", European Integration Online Papers 12, 5 (2008).

24 Andy Storey, "Normative power Europe? Economic partnership agreements and Africa", Journal of Contemporary African Studies 24, 3 (2006): 331-346. 


\section{The EU's self-portrayal}

The EU's self-portrayal seemed to resonate very much with the image of being a 'distinct' development partner rather than a traditional business partner. ${ }^{25}$ The EU was eager to display a development-oriented actor motivation and the pursuit of own commercial interests was explicitly rejected. Solidarist negotiation principles were highlighted rather than traditional tit-for-tat trade bargains.

\subsection{Actor orientation}

The actor orientation reflected in the EU's public self-portrayal clearly followed the image of a development partner. First of all, EU officials vehemently neglected the pursuit of commercial self-interests in EPA negotiations. DirectorateGeneral (DG) Trade clearly stated for instance in an official presentation on EPAs that "the EU does not have any specific offensive interest." ${ }^{26}$ European Commission representative David O'Sullivan, Director General of External Trade at the time, claimed along the same lines stating:

"I am a trade negotiator - normally a mercantilist profession! But DG Trade does not approach these negotiations in the usual way, where we seek to gain economic advantage from each other. This is clearly not the objective with the ACP. Our objective with you is to build on our privileged relationship and to secure and improve your market access into the EU, in order to serve a wider development goal."${ }^{, 27}$

The European Commission saw itself even forced to publish a leaflet on common misperceptions about the EPAs in which it reasserted that "the suggestion that the EU was motivated by commercial self interest in the EPAs is wrong." 28

EU officials moreover used the reference to development to reinforce the Union's self-image as a 'distinct' development partner in the context of trade negotiations with the ACP countries. The EU actors repeatedly stated that it seeks to advance the ACP countries' development goals. The EU-ACP trade and aid relationship was for instance proclaimed as an example for how "the Union assumes

25 Ole Elgström, "Images of the EU in EPA negotiations: Angel, demon - or just human?", European Integration Online Papers 12, 5 (2008).

26 European Commission (DG Trade), The EPA negotiations, state of play and challenges (Brussels, $31 \quad$ May 2007), <http://trade.ec.europa.eu/doclib/docs/ 2007/june/tradoc_134817.pdf> (accessed 15 April 2011).

27 Speech by David O'Sullivan at the ACP Ministerial Meeting on EPAs, Brussels, 9 November 2007.

28 European Commission (DG Trade), Six Common Misconceptions About Economic Partnership Agreements (Brussels, 11 January 2008), $<$ http://trade.ec.europa.eu/doclib/docs/2008/january/tradoc_137484.pdf $>$ (accessed 15 April 2011). 
its share of responsibility to help developing countries fight poverty and integrate into the global economy." ${ }^{29}$ The Commission repeatedly stated that EPAs should above all serve as 'tools for development. ${ }^{30}$ The European Council likewise emphasised in its 2002 negotiating mandate that EPAs must serve the objective of poverty reduction and are "above all an instrument for development."

Commission officials also highlighted the EU's responsibility to ensure a development orientation. One Commission representative argued that "from the EU side, you have to make sure in terms of the provisions, what is actually in the agreements is development oriented." ${ }^{32}$ Moreover, it was argued that the huge resources dedicated to EPA negotiations could hardly be justified from an economic point of view. If economic utility-maximisation were the dominant guiding principle, the European Commission staff would focus on negotiating trade agreements with emerging or developing countries rather than the ACP region, agreements with which affect only 2 per cent of EU imports. One Commission official argued along these lines that "if anybody in Trade would set preferences, they would look at India, Korea, MERCOSUR [...] on EPAs it is because of development. ${ }^{\text {,33 }}$

Contrasting the EU's approach directly with those of other major players was done in order to emphasise its role as a 'distinct' development partner. One Commission representative for instance argued that "what we wanted to do is precisely not to do as the others and to do something which is nicer, something which is more comprehensive. ${ }^{34}$ Doing so sets the EU apart from "really tough agreements that were negotiated for instance by the US with other developing countries [...] if they [the US] have targeted a country it is because it is interesting in terms of market access and they try to get the most out of it. But again we have accepted that we are negotiating, that we are pioneering something. ${ }^{35}$

29 European Commission (DG Trade), Trade policy (Brussels, 12 December 2009), $<$ http://ec.europa.eu/world/what/trade_policy/index_en.htm> (accessed: 19 June 2010).

30 European Commission (DG Trade), Trade and development, $<$ http://ec.europa.eu/trade/issues/global/development/index_en.htm> (accessed: 1 March 2009); see also European Commission, Recommendation for a Council Decision authorising the Commission to negotiate Economic Partnership Agreements with the ACP countries and regions, SEC (2002) 351 final (Brussels, 9 April 2002).

31 European Commission, Recommendation for a Council Decision authorising the Commission to negotiate Economic Partnership Agreements with the ACP countries and regions, SEC (2002) 351 final, 9 April 2002.

32 Interview 8, Brussels, Commission official, February 2010; Interview 10, Brussels, Commission official, February 2010.

33 Interview 12, Brussels, Commission official, February 2010.

34 Interview 8, Brussels, Commission official, February 2010.

35 Interview 8, Brussels, Commission official, February 2010. 
While it seems questionable whether the EU did indeed not perceive itself as following its own economic interests, the EU's self-portrayal clearly reflected the narrative of acting as a friend of the developing world. Both the emphasis on the development objective, as well as the rejection of commercial interests as motive, underline that the EU's self-portrayal resonates with the role of a 'distinct' development partner, rather than a traditional business partner in trade.

\subsection{Negotiation principles}

With regard to the perception of dominant negotiation principles, solidarist values were repeatedly referred to in official statements. The Council decision authorising the Commission to negotiate EPAs emphasised that the approach should be "as flexible as possible", while "negotiations shall take account of the level of development and the socio-economic impact of trade measures on ACP countries." ${ }^{36}$ The non-coercive approach was further emphasised by a statement on DG Trade's homepage, declaring that "instead of imposing development strategies, EPAs ask countries to determine their own development strategies and the pace and sequence of reform decisions" ${ }^{37}$ In general, commission officials emphasised that they do not aim to force $\mathrm{ACP}$ countries into signing any kind of agreement. ${ }^{38}$ A representative from DG Trade for instance claimed that "no one forces you to swallow up any proposals that you don't like. You can leave at any point. ${ }^{39}$ Another official claimed that there was a reluctance to impose the EU's position, as "ultimately it is in the realm of domestic policy so you cannot go and tell them what to do. ${ }^{, 40}$ Moreover, the different levels of development were portrayed as a reason for introducing a more flexible, asymmetrical approach in negotiations. It was argued that "they have different levels of development, hence there is a cause for asymmetry, hence we do not ask that they do the same". ${ }^{41}$

Overall, therefore, the strong emphasis on refraining from imposing the agreements while introducing flexibility and differentiation, reasserts that the EU

36 European Commission, Recommendation for a Council Decision authorising the Commission to negotiate Economic Partnership Agreements with the ACP countries and regions, SEC (2002) 351 final, Para 4.1(Brussels, 9 April 2002).

37 European Commission (DG Trade), Economic Partnerships,

$<\mathrm{http}: / /$ ec.europa.eu/trade/wider-agenda/development/economic-partnerships/> (accessed: 15 October 2010).

38 Interview 11, Brussels, Commission official, February 2010; Interview 8, Brussels, Commission official, February 2010; Interview 9, Brussels, Commission official, February 2010.

39 Interview 11, Brussels, Commission official, February 2010.

40 Interview 11, Brussels, Commission official, February 2010.

41 Interview 11, Brussels, Commission official, February 2010. 
portrayed its role rather as a distinct development partner than as a business partner when interacting with the ACP region in EPA negotiations.

\section{West African perceptions of the EU's role}

West Africa was selected as a case because the EU's promise to negotiate 'development' rather than 'commercial' agreements seems to have been of particular importance in this negotiating region. 13 out of the 16 countries comprising the region are Least Developed Countries (LDC) and could rely on the Everything But Arms trading scheme as a fallback option. Therefore, the economic incentives to sign an EPA agreement were less straightforward than in the case of non-LDC countries. The latter needed to negotiate an agreement to secure the continuity of duty-free and quota-free market access beyond the 2007 negotiating deadline. In the case of LDC countries, the advantages of EPAs were largely dependent upon the EU's willingness to provide flexibilities beyond the reduction of tariffs as barriers to market access. More generous rules of origin as compared to the Everything But Arms regime were for instance often quoted as an incentive for signing an agreement. ${ }^{42}$ Given the region's limited bargaining power, however, the likelihood of negotiating favourable agreements thus depended in part on perceiving of the EU as a partner who is willing to take into account development concerns.

The empirical material indicates, however, that trade representatives mostly did not share the EU's self-image as a 'distinct' development partner in EPA negotiations. Instead, the EU was much more perceived as a business partner that follows its own commercial interests. The negotiation style was moreover criticised for disregarding solidarist negotiation principles, indicating a huge gap between the EU's and the West African understandings of the EU's performance in EPA negotiations.

\subsection{Actor orientation}

The region as a whole refused to sign interim EPAs at the end of the 2007 negotiating deadline with the exception of the non-LDC countries Ghana and Cote

42 Davina Makhan, Linking EU Trade and Development Policies: Lessons from the ACPEU trade negotiations on Economic Partnership Agreements, GDI Studies 50 (Bonn: German Development Institute Studies, 2009), 11; Mareike Meyn, Economic Partnership Agreements: A Historic Step Towards a Partnership of Equals?, ODI Working Paper 288 (London: Overseas Development Institute, 2008), 3. 
d'Ivoire. Senegal's Trade Minister Mamadou Diap complained in 2006 that "to date our development needs and concerns have not been taken on board by the EU". ${ }^{43}$ Ablassé Ouédraogo, special adviser to the executive President of the Economic Community of West African States (ECOWAS) formally conducting the negotiations, similarly complained that the EU's proposals did not reflect the region's development needs. Instead of portraying the EU as a friend, it was regarded as a competitor: "Les Européens ne vont pas créer d'argent pour financer le développement de leurs partenaires qui deviendront leurs concurrents directs. ${ }^{, 44}$ These public complaints, however, could easily be discredited as part of a negotiation strategy to receive more concessions from the European side.

The general impression from the interviews present a mixed picture: they clearly confirm that the EU's affirmations not to follow its own commercial interests held little credibility in the eyes of West African trade representatives. Perceptions, however, were more nuanced with regard to their assessment of the EU's willingness to promote development goals. Some West African actors highlighted that the EU in general can be considered as a 'friend' of the developing countries. With regard to the EPA negotiations, however, most complained that the EU did not sufficiently show its commitment to reaching a developmentoriented agreement.

A high number of trade policy representatives stated without hesitation that they perceived the EU as pursuing above all its own market access interests. ${ }^{45} \mathrm{~A}$ Brussels-based trade official from the West African region claimed for instance that

"what they want is the market access, they want to bring in their goods, that's basically what they want. [...] Do you think the Europeans will say, let's do it for them? No, they have their own interests." 46

A West African capital-based trade representative said that he personally believes that the "EU is trying to have another dumping ground for their products" ${ }^{47}$ Another West African representative likewise argued that in EPA nego-

43 Mamadou Diap speaking at the conference $A C P$-EU Trade Relations: the Development Challenge of EPAs (Brussels: October 2006),

$<\mathrm{http}: / /$ www.southcentre.org/Events/2006Oct_EPA_conference_Report.pdf $>$ (accessed: 18 August 2008).

44 Quoted from "Ablasse Ouedraogo: 'Au Burkina, c'est la malédiction des 3 M", Lefaso.net, 19 August 2009.

45 Interview 1, phone-to-Brussels, embassy official, January 2009; Interview 2, phone-tocapital, government official, September 2008; Interview 3, phone-to-capital, government official, September 2008; Interview 4, phone-to-Brussels, regional trade representative, September 2008

46 Interview 5, Brussels, embassy official, July 2008.

47 Interview 3, phone-to-capital, government official, September 2008. 
tiations, the EU is interested in "keep[ing] their market, it is the biggest market in the ACP. ${ }^{48}$ These outside perceptions stand in stark contrast to the EU's selfimage, and the explicit rejection of the motive of commercial interests in EPA negotiations. Interestingly, ACP actors seemed to have less of a problem than EU officials with acknowledging the mutual pursuit of commercial interests in EPA negotiations. While Commission officials fiercely rejected that economic interests were important, on the West African side there seemed to prevail an understanding that the EU necessarily needs to pursue own economic interests because "at the end of the day, they have to protect their own interests, whether you like it or not." 49

Reactions to the EU's affirmation to follow development goals when negotiating trade with the ACP countries varied more, and were at times contradictory. There was no clear opinion on whether to acknowledge the EU's general willingness, or good intentions, to promote development. Yet, most interviewees portrayed the EU as lacking flexibility in EPA negotiations. Bad intentions were mostly not ascribed to the EU, with one respondent even recognising that "they are trying to help us" or that "the EU understands it cannot go all the way with trade." ${ }^{50}$ With regard to the general relationship between the partners, a respondent to the questionnaire emphasised that "l'Union Européenne dans son ensemble est grande pourvoyeuse de l'aide au développement." ${ }^{, 51}$ Other voices were more critical. One representative of ECOWAS complained that in the case of EPAs "the EU does not have the political will to accept an agreement that is prodevelopment. ${ }^{152}$ The skepticism with regard to the EU's proclaimed actor orientation seems worrisome from the European perspective, if the EU is serious about establishing itself as a genuine partner of the developing world.

\subsection{Negotiation principles}

While the EU portrayed itself as taking on a flexible, non-forceful approach, West African representatives painted a very different picture. The EU was criticised for not sufficiently paying attention to solidarist principles such as flexibility or care. Again, outside perceptions of the EU's role were much closer to the image of business partner than of a 'distinct' development partner.

48 Interview 4, phone-to-Brussels, regional trade representative, September 2008.

49 Interview 1, phone-to-Brussels, embassy official, January 2009.

50 Interview 1, phone-to-Brussels, embassy official, January 2009.

51 ECOWAS representative questionnaire response, February 2009.

52 Interview 5, Brussels, embassy official, July 2008. 
Official statements indicate that the EU was hardly seen to act as the development-friendly partner it claimed to be in the negotiations. The ACP Council of Ministers formally lamented that the conclusion of interim agreements was reached "contrary to the spirit of the ACP-EU partnership" ${ }^{53}$ Other ACP government officials decried the divide and rule tactics being advanced by the European side,$^{54}$ depicting EPAs as yet another "scramble for Africa". ${ }^{55}$ Talla Fall, 'chargé d'affaires' of the Senegalese Embassy in Brussels, bluntly stated that "African states had been divided up as had been done in colonial times." ${ }^{56}$ Perceptions of insensitivity on behalf of the EU to the particular development needs of the ACP region were also expressed in a statement by Sierra Leone's Deputy Bank Governor Alhaji Mohamed Fofana at a stakeholder seminar:

"The proposed EPAs are interpreted as a diversion from the basic principles that should guide the EU/ACP arrangements and as a reflection of insensitivity on the part of the EU to the genuine interests of development and cooperation. [...] Part of the contention is that this stipulation ignores the extent of economic disparity between the partners and is fraught with implications that are detrimental to the ACP countries." 57

Along similar lines, the interviewees criticised the lack of flexibility in the EU's approach ${ }^{58}$ suggesting that these narratives reflect genuine perceptions. For instance, a West African trade consultant complained that "unfortunately, they did not give much flexibility and leeway to us" ${ }^{59}$ It was argued that the EU could "at least give in to certain concessions in order to move the process forward", or be more understanding, as "we are not at the same level of development." ${ }^{, 60}$ A Brussels-based trade representative complained that the development needs are not sufficiently considered in EPA agreements because "the EU does not care about all this" ${ }^{61}$ Highlighting perceptions of the EU's lack of care is a clear reference to solidarist negotiating principles, the honouring of which would be expected from a 'distinct' development partner. The EU was moreover criticised for

53 ACP Secretariat, Declaration of the ACP Council of Ministers at its 86th Session Expressing Serious Concern with the Status of the Negotiations of the Economic Partnership Agreements (13 December 2007).

54 "Malawi maintains 'no' stand on EPAs", Bilaterals.org, 27 July 2010.

55 Former President Benjamin Mkapa quoted in "EU faults Mkapa on Epa", Allafrica.com, 6 April 2010.

56 “Africa: Live With EU's Contradiction”, Afrol News, 15 July 2008.

57 Speech by the Deputy Bank Governor Alhaji Mohamed Fofana, National Seminar on the Economic Partnership Agreement, Bank of Sierra Leone, Sierra Leone, 12-13 December 2007.

58 Interview 6, phone-to-capital, government official, January 2008; Interview 7, phone-tocapital, trade policy expert, October 2008; Interview 5, Brussels, embassy official, July 2008.

59 Interview 7, phone-to-capital, trade policy expert.

60 Interview 1, phone-to-Brussels, embassy official, January 2009.

61 Interview 5, Brussels, embassy official, July 2008. 
putting too much pressure on the ECOWAS region. One respondent to the questionnaire argued that the region would consider an EPA only "à condition que les négociations soient dépourvues de toute forme de pression." ${ }^{62}$ The way in which Trade Commissioner Peter Mandelson conducted the negotiations was criticised as "top-down" and "very rigid". ${ }^{63}$ Moreover, the signature of individual Interim EPAs with Ghana and Cote d'Ivoire close to the 2007 negotiating deadline was perceived to split the region, thus undermining regional integration. In this respect, a West African government official made the argument that the "EU wanted to divide our countries to impose a position - this is not a good thing, and our President was really angry."

West African perceptions of the EU's role in EPA negotiations therefore diverged significantly from the EU's self-image as promoted both in official statements and the private interviews. These findings indicate a huge gap between the EU's and the West African representatives' perception of the consideration of solidarist negotiation principles in the case of EPAs. If the EU intended to act as a 'distinct' development partner, it failed to get its message across the negotiating table.

\section{Conclusion}

The launching of EPA negotiations in 2002 represented the latest, ambitious attempt to reform the trade regime between the EU and ACP countries. Agreements were supposed to introduce reciprocal liberalisation of "substantially all trade" and to foster development and regional integration in the ACP regions. After almost 10 years of negotiations, and the passing of the official 2007 WTOrelated negotiating deadline, both sides have come to acknowledge that the lack of progress has been disappointing. ${ }^{65}$ This chapter has highlighted one particular aspect that contributed to the deadlock in negotiations: both sides disagreed on the role the EU was playing in the negotiations. The EU portrayed its role as a distinct development partner that does not primarily pursue its own economic interests in trade negotiations with the ACP group. When looking at the West African negotiating region, however, outside perceptions of the EU's performance

62 Ibid

63 Interview 6, phone-to-capital, government official, January 2008.

64 Interview 7, phone-to-capital, trade policy expert, October 2008.

65 Dr Mohamed Ibn Chambas, Secretary General of the ACP quoted in: "ACP wants regional EPAs, not interim agreements with individual members", Vanuatu News, 5 August 2010. Note that in contrast to the Pacific and the African negotiating regions, the comprehensive EPA concluded with the Caribbean negotiating region in 2007 is regarded as a success story by the EU. 
clearly indicated that the EU was perceived to follow above all its own market access considerations. In contrast to the self-portrayal as a considerate, flexible development partner, the EU was criticised for using divide-and-rule tactics. A lack of flexibility and a great deal of insensitivity were lamented. While a more comprehensive basis of empirical data would be needed to substantiate these trends and generalisations about outside perceptions of the EU's role, they indicate that a discrepancy between perceptions persisted beyond the level of public, and oftentimes strategic, declarations. As a consequence of these diverging understandings of the EU's role in EPA negotiations, Klaus Rudischhauser, director of ACP relations in the European Commission, admitted that EPA negotiations have been a "public relations disaster for the Brussels bureaucracy", and "a huge communications failure. $" 66$

But what lies at the heart of the observed divergence in perceptions? Is it merely a matter of communication? Taking into account economic impact assessments suggest that the region's skepticism towards the proposed EPAs is not entirely without foundations. While most analyses highlight that signing an agreement could potentially lead to a positive improvement of the economic situation, ${ }^{67}$ these benefits are made dependent upon a number of contingent factors, many of which do not seem to be in place. For instance, losses in tariff revenue income might exceed gains from trade. The envisaged tariff revenue losses could potentially be offset by an increase of the tax rate. Yet, the dominance of the informal sector leads to a situation in which many economic actors escape taxation. ${ }^{68}$ While economic analyses are certainly important in judging the accuracy of both side's perceptions, they fail to explain why both the EU and West African countries seem to be trapped in a situation of mutual misunderstanding: while it seems cynical to totally dismiss the possibility that some of the EU's negotiators - especially within DG Development - are indeed to some extent driven by the desire to negotiate a 'development' agreement, the other side clearly does not perceive the EU to act as a 'friend' of the developing world. Is the EU sitting in the same boat as China, the allegedly self-interested trade and development partner in Africa? The answer is likely to depend on a complex interplay of factors which lie beyond the scope of this chapter. It can be suspected that the EU follows both development and commercial interests in the EPA negotiations.

66 "Deals with Africa a 'PR Disaster"', Inter Press Service, 26 February 2008.

67 See for instance Martin Busse i.a., The impact of ACP/EU Economic Partnership Agreements on ECOWAS countries: An empirical analysis of the trade and budget effects (Hamburg: Institut für Wirtschaftsforschung, 2004); Pricewaterhouse Coopers, Sustainability Impact Assessment of the EU-ACP Economic Partnership Agreements. Summary of key findings, policy recommendations and lessons learned (2007).

68 David Laborde, "Fiscal impact of the Economic Partnership Agreement in West Africa", Trade Negotiations Insights 9, 6, (July 2010). 
This creates ambiguity with regard to the EU's motives, which is likely to complicate any signaling or trust-building efforts. Moreover, the image of a 'friend' of the developing world is far from clear-cut. Does it imply that the EU needs to provide financial support in EPA negotiations? Or does it rather refer to the provision of technical support and advice? How should the negotiating position of a 'friend' be evaluated with regard to technical negotiating issues? Are demands of reciprocal tariff cuts appropriate, if acting as a friend of the developing world? Clearly, diverging interpretations of the implications that follow from the commitment to act as a distinct development partner easily allow for a discrepancy between self-portrayal and outside perceptions.

What are the implications that follow from the existence of divergent portrayals of the EU's role? If the EU wants to position itself as a distinct development partner in its trade relations with ACP countries, it needs to be perceived as such. The willingness to provide for flexibilities is crucial in this regard. Moreover, the EU needs to be more up-front about what it attempts to achieve in negotiations, be it for the sake of reducing ambiguity about what it means when portraying itself as a 'friend' of the developing world.

Ultimately, the gap in perceptions of the EU's motives might in itself be indicative of the changing role of the EU's external policies vis-à-vis its - mostly former colonies in the ACP regions. Current political realities seem already much closer to a business partner relationship than the EU's rhetoric suggests. The EU's affirmations of not following its own commercial interests seem more and more out of place as they are neither regarded as credible, nor possible. Yet, the transition of the EU-ACP trade relationship from an era of unilateral preferences managed by DG Development towards more 'business-like' reciprocal trade agreements does not promise to be a smooth process. After all, huge economic disparities persist between the partners and limit the ease with which mutual obligations could or should be built up. The fierce criticism regarding the EU's role in EPA negotiations points at the pressing need to reach agreement on the role the EU plays towards ACP countries in the $21^{\text {st }}$ century. Otherwise, a deeper seated disagreement on what behaving as a development partner implies in the context of trade negotiations might complicate, or even prevent, cooperation between the EU and ACP countries in the future. 